\title{
Political parties in Ghana: agents of democracy?
}

\author{
Anja Osei* \\ Department of Politics and Management, University of Konstanz, Konstanz, Germany
}

\begin{abstract}
Political parties are generally thought of as agents of democracy that fulfil a range of functions, such as policy formulation, interest aggregation and articulation, social integration, and elite recruitment. However, given the weakness of many African parties, are they able to contribute positively to democracy? This article seeks to answer this question by using Ghana - one of Africa's most successful democracies as a case study. It is found that parties in Ghana are comparatively strong and do indeed mobilise large numbers of voters. They even expose a degree of ideological competition and have successfully adapted their strategies to the local context. On the other hand, they expose serious weaknesses in the field of social integration and interest representation. Against this background it is argued that even in procedurally well-functioning democracies like Ghana, political parties can be instruments of elite competition that contribute to the exclusion of the poor from decision-making.
\end{abstract}

Keywords: Ghana; political parties; democracy; representation; party functions

In the early 1990s, scholarly discourse placed much hope on the democracy promoting functions of civil society (see, among others, Diamond 1994). Political parties, in contrast, were a relatively neglected topic in African Studies for a long time. The revitalisation of party research in Africa began only at the end of the twentieth century and followed the general trend of a worldwide revival of the sub-discipline.

Although research on political parties has made some progress in the last decade there is still little empirical knowledge on party organisation, social anchorage, party strategies, programmatic appeals, and on the relationship between parties and democracy. Most typically, African parties are presented as 'weak' parties. They are said to lack a stable and functioning party apparatus and active membership (Erdmann 2002, 268; see also Manning 2005). Their programmatic appeals amount to little more than populism: they make vague promises of fighting corruption and a better future for all (van de Walle 2003, 304) and fail to mobilise citizens along substantive issues (Bleck and van de Walle 2011). Thus, political parties in Africa appear less as the expression of group interests than as projects of political entrepreneurs who can afford paying the campaign costs from their own pockets (Tetzlaff 2002, 243).

Because of these weaknesses, the possible contribution of political parties to democratic development is often questioned (Randall and Svåsand 2002; Emminghaus 2002). However, given the variation of democratic development on the continent, this issue deserves to be explored in more depth. In the case of Ghana, Whitfield $(2009,640)$ 
has argued that the institutionalisation of political parties has played a positive role in the process of democratisation. This article aims to contribute to our understanding of the relationship between parties and democracy in Ghana. Field research took place in Ghana between 2006 and 2008. Semi-structured interviews were conducted with party representatives at different levels of the party hierarchy in selected constituencies which included the strongholds of the three most important parties. The parties under consideration are the New Patriotic Party (NPP), National Democratic Congress (NDC) and People's National Convention (PNC). The decisive criterion for their selection was the number of seats won in the parliamentary elections in 2000. The research also incorporated quantitative data, such as election data and data from the Afrobarometer survey, which are available on the networks' website (www.afrobarometer.org). Additionally, a small survey $(N=120)$ on voters' opinions was conducted in cooperation with a local partner institution. The survey is not representative in the statistical sense. Its purpose is rather to complement the qualitative data, and as such, the quantitative interviews were conducted in the same constituencies as the qualitative ones.

The article begins with some general reflections on parties and democracy. Although the functional approach will be critically reviewed, the 'classical' party functions are taken as a starting point for the empirical analysis. The concluding remarks will then assess what parties in Ghana contribute to democracy and where their deficits are.

\section{Parties and democracy: the chicken or the egg?}

Transitions from authoritarian rule often started with popular protest by civic associations, trade unions, students' and women's organisations, professional associations, churches and many others (see Bratton and van de Walle 1997, 117). Multiparty democracy became the rallying cry of these heterogeneous opposition coalitions that were kept together mainly by their hostility to the old regime. Yet the more the restrictions on political activities were lifted, the more civil society groups were replaced by political parties. Most of the parties that were mushrooming in the 1990s were either large opposition coalitions assembling diverse interest groups, or small and often highly personalised parties. The leaders of these parties were often familiar faces. Many of them had once belonged to either the incumbent or a previous regime (Wiseman 1998, 54). Very often, these oppositional elites had an instrumental understanding of multiparty politics. To them, multipartyism was just a way (back) to power (Aké 2000, 133) and they had little interest in elaborating coherent ideologies. Thus, political competition was reduced to leadership alternation.

Many authors have underlined the fact that democratisation has not fundamentally changed the nature of power in the African state. Chabal $(2005,20)$ notes that 'political competition means more acute rivalry among the elites for control of the state'. In many cases, incumbents continue to stay in power, appoint handpicked successors, or are succeeded by family members (Nwosu 2012, 17; see also Lynch and Crawford 2011, 283). Although almost all African countries hold multiparty elections, many of them are still stuck in a 'gray zone between full-fledged democracy and outright dictatorship' (Diamond 2002, 23). The emergence of such hybrid regimes has spurred discussions about the necessary conditions for successful democratic change. While there are a range of factors that possibly influence the success of transitions, political parties are generally among the institutions which are thought to fulfil functions that are indispensable for democracy. 
While this may be convincing at first sight, the link between parties and democracies is not quite clear. Or, in the words of Sindjoun (2010, 3): 'which makes which?' Mansfield and Snyder $(2005,2)$ hold that strong institutions such as an effective state, the rule of law, organised parties and news media are needed to make democracy work (see also Berman 2007, 30). However, if organised parties are seen as a precondition of democracy it is not clear how they can be built in the course of democratisation. Under autocratic and repressive regimes, it is unlikely that well-organised parties will develop before democratisation, exactly because authoritarian leaders often restrict the building of alternative organisations. The first parties that appeared in the course of political liberalisation in Africa were rather loosely organised opposition coalitions that pushed for their legalisation. Many autocrats managed to control the speed of liberalisation and used the legalisation of political parties as a tool against the opposition, as it was done by Jerry Rawlings. In Ghana, the ban on political parties was lifted on 1 May 1992, presidential elections were scheduled for November and legislatives for December, thus leaving no time for the oppositional groupings to transform themselves into well-organised parties (see also Jeffries and Thomas 1993, 339).

While weak parties may have negative consequences for interest representation, they are not the only institutions with shortcomings (Carothers 2006, 11). Representation also requires a citizenry capable of expressing collective interests and a state capable of responding to these interests (Carothers 2006, 12). This suggests that while democratic parties could be regarded as a necessary condition for democracy, there might be preconditions for the development of efficient parties as well. Randall and Svåsand (2002, 15) name urbanisation, educational level and general improvement of living conditions as factors which enhance the development of efficient and democratic parties. High levels of urbanisation and intact infrastructures facilitate communication with party sympathisers and voters, whereas improved education levels and higher living standards raise the awareness of voters and their ability to contribute financially to political parties (Randall and Svåsand 2002 , 16). Furthermore, the continued persistence of non-democratic practices is limiting the efficiency of opposition parties in various ways. Election campaigns are often an unlevel playing field in which incumbents 'obstruct, weaken, harass and divide the opposition' (Olukoshi 1998, 29). The room for political opposition is therefore often limited (Uddhammar, Green, and Söderström 2011; see also Rakner and van de Walle 2009). Incumbent parties frequently try to determine the rules of electoral competition to their own advantage, they deny the opposition access to the media, make use of state resources for their own election campaigns, try to manipulate voters' registers, or introduce constitutional changes in order to keep potentially dangerous oppositional forces away from power. Under these circumstances, the growth of a strong parliamentary opposition which can hold ruling parties responsible is seriously endangered.

The relationship between political parties and democratic quality seems to be - at least in Africa and possibly in other new democracies - a chicken-and-egg-problem: parties should enhance and improve democracy, but at the same time, the hybrid environment of authoritarian and democratic practices undermines the very organisational capacities of political parties.

\section{The functional approach and the Western bias}

Van Cranenburgh takes a very pessimistic point of view and underlines that African parties 'as they function at present' $(1999,104)$ are not agents of democratisation. In fact, 
political parties do not conform to the ideal of effective parties which should have a strong central organisation, be internally democratic, have clear ideologies, transparent and adequate funding, a well-defined membership base and cooperative relations with civil society organisations (Carothers 2006, 98). Policy makers and providers of party assistance therefore, seek to reshape them along those lines (Carothers 2006; see also Erdmann 2010). External assistance thus aims at transforming 'weak' and 'dysfunctional' parties into 'strong'parties that are 'functional' for democracy (Erdmann 2010, 8).

There is a wide range of democracy-promoting functions that parties are thought to perform. For example, Gunther and Diamond (2001, 7-8) name the following seven functions: candidate nomination, electoral mobilisation, issue structuring, societal representation, interest aggregation, forming and sustaining governments and social integration. Von Beyme (1982, 25) identifies four functions: agenda-setting (ideology and programme), interest articulation and aggregation, mobilisation and socialisation, elite recruitment and government formation. There are a number of slightly different catalogues, but these two examples encompass the most frequently mentioned party functions (see also Wiesendahl 1980, 188 for an overview).

Two problems arise in the African context. The first one is that of the 'Western bias' (Erdmann 2004). As Erdmann (2004) has observed, many contemporary concepts of party research are biased towards a 'Western' understanding of parties as mass-based organisations and are thus not easily applicable to other regions of the world. The mass party is clearly a child of its time and place. In the late nineteenth and early twentieth century, mass parties emerged as the organisational form of the working class and campaigned for social and political rights. The evolution of this type of organisation was embedded in the context of industrialisation, urbanisation and mass communication, but it was also linked to the development of democracy. For example, the franchise was only granted to women, workers and racial minorities after long struggles in which especially the social-democratic parties played a role. Consequently, party development cannot be isolated from democratic development in general, and democracy itself is to a great extent the product of social struggles of the underprivileged classes (Therborn 1977, 35). Yet, even in Europe parties are undergoing a process of change. They are losing members, are less strict in their ideological orientations, become more disentangled from civil society groups, and more volatile (von Beyme 2000). Such party change is an adaptation to complex processes of social change, like expanding middle classes, migration, postmaterial values and mass communication (Gunther and Montero 2002, 8; Poguntke 2003, 11; von Alemann 2002). As a result, parties in Western Europe have become more electoralist over time, even though they can still build on the organisational capital from their time as mass-based parties (Carothers 2006, 53). It is interesting to note that this party change is often described in a negative terminology, almost as a deviation from what parties ought to be. It seems that the ideal version of party is still that of the mass party with an extensive organisational network, strong ideological orientations and the important role of party members for funding and campaign activities (Kirchheimer 1966; von Beyme 2000, 27; Katz and Mair 1995, 8-12). Parties in Africa are thus pitted against an ideal that is ceasing to exist even in the West.

The second, and related, problem of the functional approach is the "purposive and teleological connotation' (Sartori 1970, 1047) that it carries. The purpose, or telos, is of course a functioning democracy. However, democracy is a contested concept and different conceptions of democracy may correspond to different sets of expected party functions. Today, many scholars resort to procedural definitions of democracy which 
exclude social rights. One of the most commonly used definitions is Dahls' 'polyarchy', which focuses on free and fair elections and popular participation. ${ }^{1}$ While free and fair elections are a necessary feature of democratic regimes, a procedural definition bears the danger of ignoring informal practices that could distort democratic structures. Secondly, the dissociation of democracy from its social origin neglects important historical trajectories. Ironically, while the classical party functions are deduced from the history of the mass party, the social origin of this type and its connection to a specific conception of democracy is often ignored. Katz and Mair (1995, 6 and 21-22) remark that the mass party-type corresponds to a version of democracy in which well-defined social groups make demands on the state and engage their members in the formulation of programmes. Thus, if democracy is thought of as a participatory system, in which political parties are means for the representation of citizens' interests and their social and political advancement, then the functions of social integration, policy formulation and interest articulation feature prominently. If, in contrast, democracy is thought of as a political market in the sense of Downs (1957), then the core function of parties is that of elite recruitment and government formation. According to this view, the primary task of political parties is to participate in elections and to allocate positions of power to their leaders whereas interest articulation becomes just a by-product of vote-maximising strategies (Wiesendahl 1980, 206). A third reading would suggest that parties are 'gate-keepers' that lend legitimacy to a given system by filtering and aggregating societal demands before they begin to threaten the whole system (Wiesendahl 1980, 202). In this version, the aggregation function might be the most important, but it might come at the expense of the articulation function. As the latter two conceptions of party functions show, the disentanglement of parties from their social milieus and well-defined groups or a loss of clear ideologies is not an immediate problem for 'thin' definitions of democracy. As Katz and Mair argue, parties in an electoralist democracy 'are partnerships of professionals, not associations of, or for, the citizens' $(1995,22)$.

All these things have to be borne in mind when thinking about parties in Africa, which probably never conformed to the ideal of the mass party (Erdmann 2002, 260). Under the conditions of an uneven and weakly developed infrastructure, low living standards and low education, the model of the mass branch party can hardly work in Africa. Therefore, the specific context of existence of African parties must be taken into consideration in any analysis. However, while it is problematic to apply biased concepts, it is equally difficult to construct new concepts while there is little empirical knowledge (Basedau, Erdmann, and Mehler 2007, 278). Thus, falsification and the identification of differences can be regarded as a first step (Burnell 2007, 66) in the research process. Although the functional approach is highly problematic, the 'classical functions' are still taken as a starting point for the analysis of Ghanaian parties. The seven functions proposed by Gunther and Diamond (2001, 7-8) are collapsed here into four categories: (1) policy formation and issues structuring; (2) societal representation and interest aggregation; (3) electoral mobilisation and social integration; (4) candidate nomination and forming governments. After some general remarks about Ghana's parties, this framework will be applied to the case study, and the performance of the parties in these four areas will be assessed.

\section{Ghana - a strong democracy because of strong parties?}

Despite a very eventful political history, Ghana is one of the most stable countries on the African continent today. The keenly contested 2008 elections resulted in the second 
democratic and peaceful transfer of power since the return to multiparty democracy in 1992. The country has thus passed Huntington's (1991) 'two turnover-test' ${ }^{2}$ of democratic consolidation. Moreover, Ghana has one of the few two-party systems in Africa with two major parties of almost equal strength. These facts make Ghana an ideal case to study the relationship between parties and democracy.

The Ghanaian party system is dominated by the two major parties NPP (New Patriotic Party) and NDC (National Democratic Congress). Together, they hold 222 of the 230 seats. Of the other five parties that took part in the elections, only the PNC (People's National Convention) and the CPP (Convention People's Party) made it to parliament.

In Ghana, political parties are objects of passionate support. Electoral politics is sometimes seen as the Ghanaians' 'favourite sport' (Jeffries 1980, 407). ${ }^{3}$ Qualitative and quantitative field data support the view that parties have struck deep roots in the society and enjoy a high acceptance. According to the Afrobarometer, roughly two thirds of Ghanaians feel close to one of the political parties. ${ }^{4}$ Party identification must not be confused with party membership. Notions of party membership differ significantly across countries and regions of the world. The idea of party membership in a Western sense is only partly applicable to Africa, where party members are not always distinguishable from mere followers. For this reason, the voter survey asked a threefold question: (1) 'Are you a member of any political party in your country', (2) 'Do you hold a party membership-card?', and (3) 'Do you pay party dues?' The results are displayed in Figure 1. They show that one-third of the respondents claimed to be party members. Of these, twothirds are in possession of a membership card and half pay membership dues. No major differences between NPP and NDC were found. The morale in the smaller parties especially the CPP - is a little bit higher, probably because affiliating with a small party does not yield immediate benefits and requires a high altruistic motivation.

Of the 40 party members, 25 hold a function in their party. About one-third of the NPP and NDC members claim to engage regularly in party political activities, one-third was active only shortly before the elections, and the remaining third was completely passive. The CPP made an exception again: all members claimed to be politically active weekly or monthly. The most frequently mentioned activities were related to election campaigns (attending rallies or helping to organise them), but also to regular activities (attending branch or constituency meetings) and to informal campaign strategies ('Explaining party programmes to my colleagues', 'Talking to people about how capable the party is').

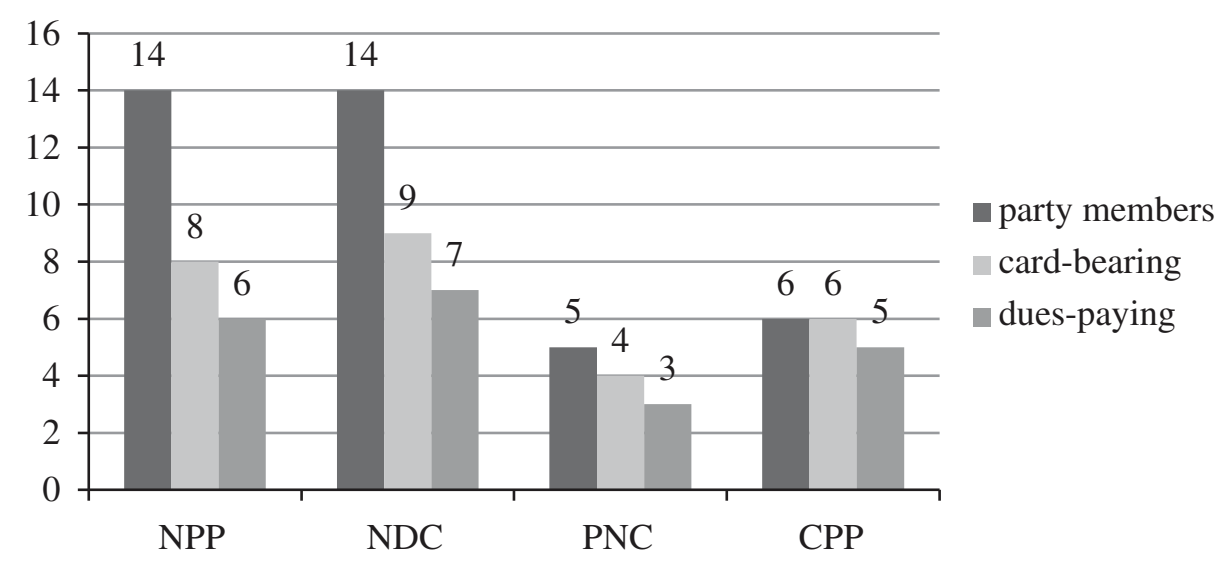

Figure 1. Party membership in Ghana, selected constituencies.

Source: Compiled by the author. 
One crucial factor for the explanation of this strength is the specific history of Ghanaian parties. Ghana's unique two-party system is the result of a historical political polarisation that dates back to a split in the nationalist movement at the eve of independence. The first political party, the UGCC (United Gold Coast Convention), was politically moderate and dominated by the wealthy and educated Akan elite in southern Ghana. Kwame Nkrumah left the party in 1947 to found the radical, left-wing CPP (Convention People's Party). Although party development was once again interrupted by military coups, every new republic saw the resurgence of the two political traditions: the Busia-Danquah tradition as the successor of the UGCC and the Nkrumahists in the spirit of the CPP. The contemporary NPP is an offspring of the Busia-Danquahists, while the smaller parties PNC and CPP claim a Nkrumahist heritage. In the Fourth Republic the NDC, a successor organisation of the PNDC (Provisional National Defence Council) of the former military ruler Jerry John Rawlings, became a strong third force that has started to take over the political space on the left that once belonged to the Nkrumahists.

\section{Party functions}

\section{Policy formulation and issue structuring}

Much of the literature on political parties in Africa stresses the lack of ideological competition. The promises that African parties make often sound very similar: better living conditions for all, less corruption, more education, more infrastructure and so on. Change is one of the most common promises and in many cases the only one.

While many scholars and experts on the country hold the view that there are few ideological differences between the major parties in Ghana (see for example, GyimahBoadi 1999, 414; Nugent 2007, 259), this statement needs some qualification. Although ideological competition is not very much in the foreground, all parties were able to give a clear outline of their political objectives in the qualitative interviews. Throughout the interviews, the NPP was remarkably coherent. All interview partners stated correspondingly that their party stands for the rule of law, (liberal) democracy/good governance and freedom (of business, of the individual). Whether or not such objectives are put into practice is yet another question but what can be safely argued is that the NPP has succeeded in giving itself a distinguishable image that is well communicated to the grassroots. To the fortune of the party, its values fit almost perfectly into the mainstream global discourse of good governance and market economy. This made the NPP as a ruling party highly compatible with the political conditionalities of the donor community. The liberalism of the NPP is not just an opportunistic accommodation to a predominant discourse, but has its origin in the political objectives of the Busia-Danquah tradition and some social values of the Akan, and especially Ashanti, societies. ${ }^{5}$ All parties of the Busia-Danquah tradition have been more or less associated with liberalism, market economy and individual freedom (Nugent 2007, 260; Jonah 1998, 90; Whitfield 2009). In the Third Republic and under the PNDC rule, the liberal opposition also campaigned for human and civil rights. Today, the NPP emphasises the 'rule of law' in order to distance itself from the NDC. The most vehement protest against Rawlings' military rule had indeed come from the Ashanti region, which was also the home of pronounced resistance against the establishment of a one-party state under Nkrumah. NPP supporters tend to reinterpret this into a general disgust of Ashanti/Akan peoples against dictatorship, but since the military rulers Afrifa and Acheampong were of Ashanti descent this is rather a 
euphemism. Around the year 2000, the NPP shifted a little more to the left. Nugent observed that the party started to exploit the sense of malaise in the cities and transformed its image of the 'the party of the patricians to a party which is at home with the plebeians' (2007, 263). Similarly, Elischer (2008) argues that there was a constant rise in left-wing statements in the party manifestos. In fact, some of the social policies, namely the school feeding programme and the National Health Insurance Scheme bear more resemblance to social democracy than to radical market liberalism. Yet, in the 2008 elections, the fault line between the liberal, 'elitist' NPP and the pro-poor NDC re-emerged. Once again, the NPP was unable to counter the image of being a party of Akan elites. The failure to address the problems that arose from the price increases in fuel and consumer products and the display of extraordinary wealth by many high-ranking NPP officials alienated the urban poor especially and cost the NPP important votes.

The NDC on its part portrays itself as a 'centre-left' or social-democratic party, placed in the middle between the 'right' NPP and the leftism of the Nkrumahists. For the NDC, social democracy:

...seeks to marry the efficiency of the market and private initiative with the compassion of state intervention to protect the disadvantaged and the marginalized and to ensure optimum production and distributive justice. ${ }^{6}$

The party claims to be 'focused on the poor, vulnerable and socially disadvantaged'. ${ }^{7}$ On the grassroots level, phrases such as 'defending the poor' and 'working for the welfare of the people' were frequently used to describe the character of the party. ${ }^{8}$ State intervention is seen as critical to securing basic social services and the pure liberalism of the NPP is outwardly rejected. The social-democratic orientation of the party is somewhat ironic if one bears in mind that Ghana was held as an IMF showcase in the 1980s under the Rawlings regime. On the other hand, a sort of social orientation and an anti-elite stance can be traced back to the Rawlings Revolution in 1979. From this point of view, the sympathy with the 'common man' is one of the founding myths of the (P)NDC. The social-democratic orientation of the NDC goes down well with disadvantaged and dissatisfied social groups in Ghana. The credibility of this message is fuelled by the myth that surrounds ex-president Rawlings. By his party fellows, he is described as a 'righteous, ordinary Ghanaian' with a 'strong sense of humanity'. 9 Even non-NDC members acknowledge his popularity, and stories like that of Rawlings once 'cleaning one of the dirtiest gutters with his own hands ${ }^{10}$ after his seizure of power in 1979, are still told in the Volta Region.

The Nkrumahists are seriously weakened by the left-wing orientation of the NDC. Essentially, the political identity of the Nkrumahists is still built around the values of PanAfricanism and socialism, but as these political orientations have become a bit out of fashion in these times, the Nkrumahists tend to speak of social justice and pro-poor policies in a broader sense. Statist intervention is still seen as a crucial factor for the achievement of these goals (see also Jonah 1998, 90; Nugent 2007, 260). In the case of the PNC, which has its main support in the very north of Ghana, Nkrumahism is coupled with a regional agenda to defend the interest of the Northerners.

This creates the impression of a left-right continuum that ranges from the liberal NPP to the social-democratic NDC and the Nkrumahists on the very left. This does not necessarily mean that there are substantial ideological differences between the parties. In 
practice, the NPP embraces social-democratic policies as well as the NDC is not principally against market reform. Yet, the master narratives of both parties are opposed to each other: the liberal values of the NPP versus the social orientation of the NDC.

Do these values, however, find a reflection in voters' attitudes? The survey results give some insight into this. In one section of the questionnaire the respondents had to assess to which degree the three parties possessed certain qualities, which were derived from the parties' self-perception. The figures for the two major parties are largely congruent with the self-evaluation of the parties. ${ }^{11}$ The core values of the NPP (rule of law, liberalism and good governance) are perfectly reflected in the survey results. The party is rated higher than the other parties in the field - 'is a democratic party', 'is a liberal party', 'respects human rights' and 'respects the freedom of expression', but it is also seen as more elitist and more ethnically based (see Figure 2).

The NDC is ahead of the other parties in the areas 'is a social-democratic party' and 'stands for social justice', yet it is also overwhelmingly associated with the ex-president

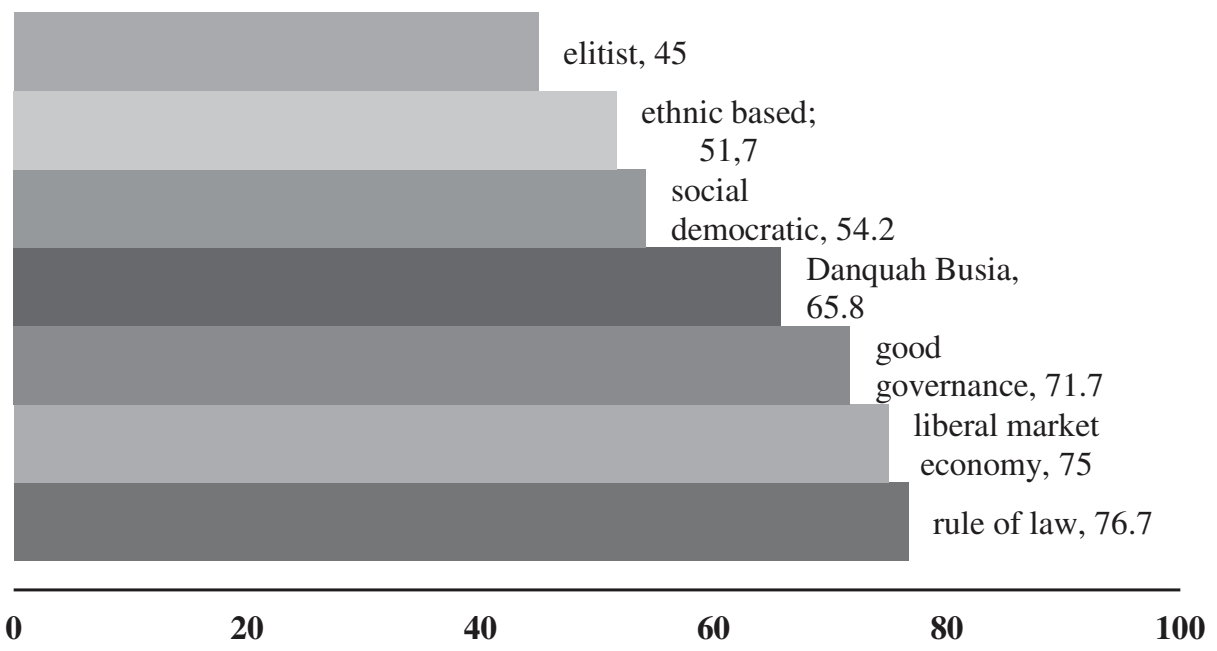

Figure 2. Voters' perceptions: What does the NPP stand for? Compiled by the author.

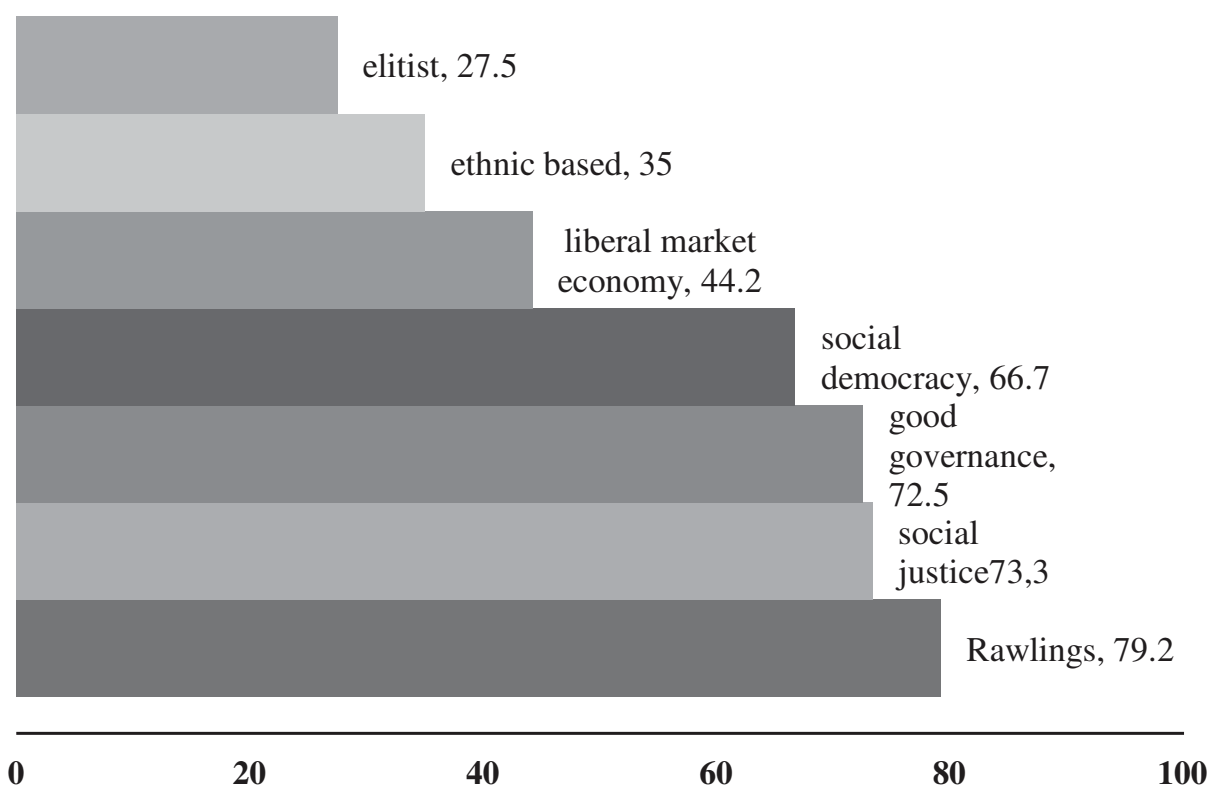

Figure 3. Voters' perceptions: What does the NDC stand for? Source: Compiled by the author. 
Rawlings. Surprisingly, the NDC is ranked higher than the NPP in the field of good governance. Altogether, an overwhelming majority thinks that the NDC is a national and a democratic party, and $71 \%$ believe that the party respects human rights. Only a minority of about a quarter of the respondents associated the NDC with military dictatorship and undemocratic rule. The rankings for 'stands for liberal market economy', 'is an ethnic based party' and 'is an elitist party' are below 50\% (see Figure 3).

In general, the ideological positions of the NPP and NDC are complementary. They are also coherent enough to give voters at least a rough orientation of what the parties claim to stand for.

\section{Societal representation and interest aggregation}

Parties represent social groups symbolically or in advancing specific interests (Gunther and Diamond 2001, 8). Furthermore, they aggregate the interests of individual groups into broader appeals (Gunther and Diamond 2001). The problematic aspect of these functions lies in the fact that they presuppose the existence of organised groups with a clearly identifiable group interest. Civil society groups in Africa, however, tend to be urban based and thus not representative of the rural majority (Widner 1997, 78). The fact that they are themselves weak and have little power to deliver their members' votes makes them only attractive for political parties (Widner 1997, 66).

Nevertheless, an alternative strategy of party-voter linkage has emerged: that of the intermediary. Political parties try to win over influential people who are supposed to deliver the votes of their respective communities. Officials of all parties made reference to this strategy. The NDC for instance sought to put up parliamentary candidates that were 'already popular in their community' 12 in preparation for the 2008 election. Intermediaries can be chiefs or other opinion leaders, such as lawyers, doctors or businessmen. Chiefs are of course a special type. In Ghana, chiefs are not allowed to campaign openly, but they still have ways and means to express their sympathy for a certain party. Before holding an open rally in a village, party representatives must 'greet the chief'. This 'greeting' normally involves the giving out of gifts for the chief and the elders and sometimes the whole village. Concerning the question of how chiefs are influencing voters, attitudes differed. Most informants in the Volta region stated that chiefs were very powerful and able to control voting behaviour in their community. It was reported that voters who did not comply with the chiefs' orders were threatened with witchcraft. ${ }^{13}$ In Cape Coast, in contrast, their influence was overall denied, and in Mampong, in the Ashanti region, the NPP incumbent was reported to have good contacts with the local chief, while his opponent had not. Much of the contact between incumbent or aspiring MPs takes place in a private form and behind closed doors ${ }^{14}$ and it can be expected that rewards to the chief and/or his community are offered in exchange for the votes.

This form of party-voter linkage is an adaptation to the local, especially the rural, context. Nevertheless it does not aggregate group interest, but rather involves clientelistic relations between local big men and the party. There are in fact little institutionalised contacts to civil society groups in Ghana. When asked for their target groups, the NDC and the Nkrumahists named broad social groups, such as 'the poor', whereas the NPP revealed a catch-all appeal and claimed to represent 'all Ghanaians'. An interesting case is the small PNC which takes a chameleon-like stance. The party is an offspring of the 
Nkrumahist tradition and traces itself back to the PNP of Dr Hilla Limann, a Northerner, who was the president of the Third Republic. According to the National Organiser M.A. Moomin, the target groups of the party are not only the Northerners but also the Muslim migrants in South Ghana. Consequentially, the PNC calls for the introduction of a 'Ministry of Zongo ${ }^{15}$-Affairs'. ${ }^{16}$ Yet the Northerners' orientation is somewhat controversial and it is the official policy of the party to deny any parochial interest.

This leads to another important point: do parties represent ethnic groups? While the assumption of ethnic voting is frequently found in the literature on political parties in Africa, it is difficult to establish a direct link between ethnicity and voting in Ghana. The Busia-Danquah tradition always performed strongly in the Akan regions, especially the Ashanti and Eastern regions. While these two regions are solid supporters of the NPP there is no Akan bloc-vote. Akan regions such as Brong Ahafo or the Central Region are difficult to predict. The NDC on its part scores its major success not only in the Volta Region - Rawlings' home region - but also in the other less-developed parts of the country: the Northern, Upper East and Upper West regions. Thus, the Akan/non-Akan pattern is also connected to a development gap between the better developed regions in the south and the poorer Volta and northern regions.

Yet, even if we can say that the Ashanti region is safely in the hands of the NPP does this mean that the party represents Ashanti interest? This question is difficult to answer. As van de Walle $(2003,313)$ argues:

Even in the absence of tangible benefits, citizens will choose to vote for individuals of their own ethnic group, particularly in ethnically divided societies. Less than the expectation that they will benefit directly from the vote, citizens may feel that only a member of their own ethnic group may end up defending the interests of the ethnic group as a whole, and that voting for a member of another ethnic group will certainly not do so.

Ethnicity can thus convey some information about the distribution of patronage that can be expected under the respective government (Posner 2005, 91). In Ghana, an ethnic arithmetic has surely influenced the appointment of ministers and other officeholders, but the link between ethnicity and patronage distribution is more complicated. In 2008, the NPP channelled patronage not to its strongholds but to those areas where the party was weak, especially to the Volta region. ${ }^{17}$ This proved to be a miscalculation. While the NPP could not maximise its votes in the NDC-strongholds, some Akan constituencies in the Western and Central Region turned their back on the party and accused the government of being non-responsive to their problems. ${ }^{18}$ Moreover, there are voters who feel represented by a certain party because of their ethnic origin and those who do not. For example, a migrant Ashanti in Upper East said that he joined the NPP precisely because he was an Ashanti and this was his proper party. ${ }^{19}$ In contrast, a man in the Ashanti Region revealed that he would vote for an opposition party in the 2008 elections, because the NPP had failed to deliver on its promises. $^{20}$

In sum, parties may appeal to certain groups, be they religious, regional, ethnic or socioeconomic in nature, but this does not mean that they represent these groups in terms of 'acting for them'. This is not different with social categories as 'the poor' or 'the unemployed'. Although the NDC has successfully appealed to the socially disadvantaged in the 2008 election, the statements were rather general in character and left open what was actually meant by 'defending the poor'. 


\section{Electoral mobilisation and social integration}

Under social integration, Gunther and Diamond $(2001,8)$ understand that parties 'enable citizens to participate effectively in the political process and feel that they have a vested interest in its perpetuation'. In spite of their often proclaimed weakness political parties in Africa mobilise substantial numbers of voters.

Parties in Ghana adapt their mobilisation strategies to the mostly rural context. Although all parties regarded the media as an important means of linking up with their voters, campaigning over the media is lopsided in two ways. On the one hand, ruling parties and the opposition are very unevenly represented in the media. Media coverage tends to be biased in favour of the incumbent. The second problem is related to the uneven spread of media access among the electorate. Newspapers or the internet are mostly restricted to educated urban elements. In the villages, the radio is often the only source of information. This double-bias limits the effectiveness of media campaigns and for this reason parties have to engage in more direct, personal forms of canvassing support. At the grass-roots level, house-to-house campaigns are one of the key campaigning instruments. In remote areas, such campaigns are an excellent way of reaching out to people who have only little access to news media. Typically, house-to-house campaigns come not only with a political message, but also with a small gift (cola, water, food, as well as drinks and cash for the elders). Other local forms of garnering support are employed not only in the campaigning season but throughout the year. Parties take advantage of any occasion where people come together, such as funerals, ${ }^{21}$ local festivals, marriages and naming ceremonies, communal labour exercises, and many more. They show their sympathy in the form of donations and at the same time they canvass support for the respective party. To an extent, social events even replace formal activities that are organised by the parties. Adding to that, local politicians often mentioned that their party was 'taking care of the people'. The motive of 'helping' and 'taking care' was prevalent in all parties in the two countries. This can take various forms: giving out of cutlasses and seeds, lending a tractor for farm work, organising football teams and matches for the youth, giving micro-credits to women or helping them to open bank accounts, taking a sick person to the hospital, helping someone with a legal problem, and many more. Mostly, the context for this was said to be a display of the goodwill of the party and its closeness to the people. What these strategies have in common is the blurring of the boundary between mobilisation and votebuying. Nevertheless, such transactions might also be embedded in a local logic of giftgiving which is further reiterated under the condition of extreme poverty. Overall, it cannot be denied that voter mobilisation is rather successful.

Figure 4 shows electoral participation rates in the five most recent elections in Ghana. From the comparatively high participation rates it could be concluded that parties in Ghana do in fact fulfil the function of electoral mobilisation.

Their performance in the field of social integration is more doubtful. In order to understand this we have to take a quick look at the grass-root organisation of parties in Ghana. The two major parties NPP and NDC are well organised on the ground and possess a network of party branches all over the country. Party offices, decorated in the respective colours, can be found along major roads even in small towns and villages. Most of these offices are used only for meetings. ${ }^{22}$ Because party branches receive little or no financial assistance from the party headquarters, the intensity of party activities varies regionally and depends on the commitment of the local personnel but also on money. The reason for the absence of a regular party life, especially in opposition parties 


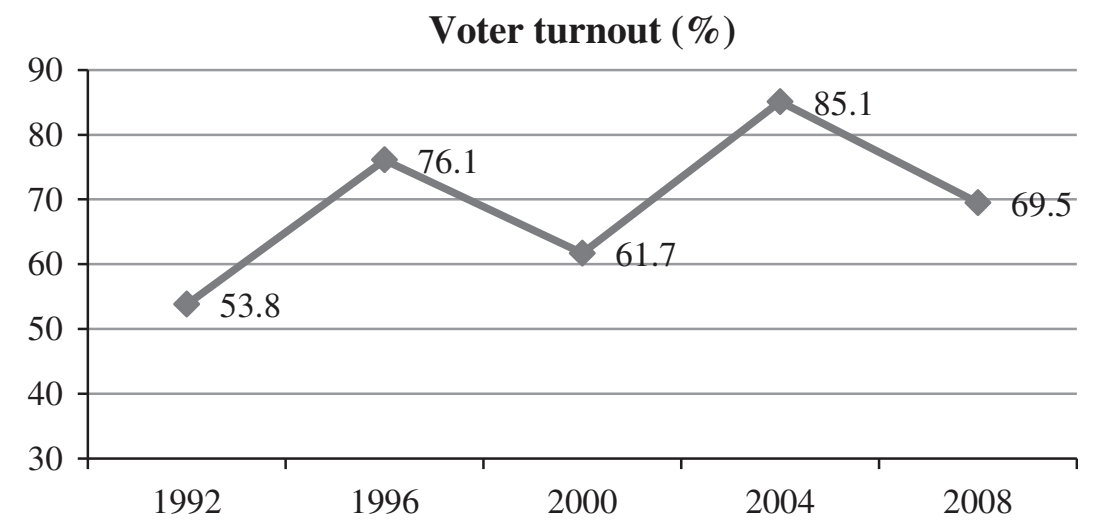

Figure 4. Voter turnout in the five most recent elections.

Source: Electoral Commission (EC), various years.

is simple: all regular activities need to be financed. Everything involves money, even if it is only a meeting at the constituency level: delegates from the polling stations will need money for their transport and have to be provided with snacks and refreshments, party offices or other meeting places have to be equipped with lights and seating. The small PNC is an example of an opposition party with very weak financial capacities. The party has only a rudimentary structure in most of the regions and no regular party life. In the Volta Region, constituency elections and a planned regional congress could not be held because of the lack of money. ${ }^{23}$ The lack of a means of transportation also constrained the campaigning efforts of the PNC: The candidate for Hohoe North, Mrs Abusuasem, did not have enough money to hire a car and so she had to go by foot. ${ }^{24}$

One consequence of this is that party competition becomes biased in favour of the ruling party. There is yet a second and equally serious consequence: the exclusion of the poor from a meaningful and active engagement in party politics. Large crowds assemble for party rallies and presidential tours, but these people are more consumers of politics than actors in the new democracies. All local party functionaries alike complained about the financial burden that their involvement placed on them. Effectively, a person with no money at all will not rise above the position of a party official at the smallest organisational level. Even in this position he may not be able to exercise his voting rights in the party if he has no money to attend a meeting in the next town. In such cases, the constituency chairman or the MP will sometimes have to provide the means of transportation for the delegates from the villages. This raises the cost of being a constituency chairman and makes politics on the grass-roots level prone to small-scale clientelism. To be a party official, even at the grass-roots level thus requires at least a regular income. A considerable amount of money is also consumed by mobile phones as the most common means of intra-party communication. For example, the chairman of the PNC Volta region said that people would often only 'missed call' him on his mobile phone expecting that he would call them back. Such things, however trivial they may appear, matter in rural Africa.

\section{Candidate nomination and forming governments}

All three parties under investigation have a more or less nationwide presence and put up candidates in most of the constituencies. Each of them also nominates a presidential 
candidate. Candidate selection processes, however, do not always follow a formal democratic script. Instances where the party leadership intervenes into the selection of parliamentary candidates are quite frequent (see Daddieh and Bob-Milliar 2012, 217). For a long time, the NDC in Ghana provided a negative example because the party primaries did not allow the rank-and-file to assert any influence and served only to confirm the nominees of the ex-president Rawlings (Debrah 2004, 5). The dissatisfaction among the rank-and-file climaxed in 1999 when Rawlings handpicked John Evans Atta-Mills as his successor at a party rally in Swedru, a step that provoked a split in the NDC. Yet the splinter groups were not able to present a credible alternative and the NDC has seemed to learn from its mistakes. The election of party leaders at the National Congress 2002 was more democratic (Boafo-Arthur 2003, 229), and the early nomination of Atta-Mills as the flag-bearer in 2007 went down smoothly. The party primaries in 2004 and 2008 although not without occasional conflicts - were not as messy as those of the NPP. Later, however, new tensions arose within the NDC, especially between Atta-Mills and the expresident Rawlings. In 2010, Rawlings' wife Nana Konadu challenged president AttaMills in the presidential primaries, but lost to him. The camp of Atta-Mills was made up of a kitchen cabinet of informal power brokers (Bob-Milliar 2012); many of whom came from the Nkrumahist tradition (Bob-Milliar 2012), or ethno-regional factions like the socalled Fante Confederacy. While there were fears that the sudden death of the president in July 2012 could usher in a new round of factional power struggles, the NDC was able to present a relatively united face in the 2012 general elections.

The NPP has always had its own headache with internal democracy. Especially in 2004 and 2008 when the party experienced considerable conflict in the party primaries. Allegations of vote rigging, vote-buying and other forms of manipulation were rife in the party primaries and the interference into candidate selection by party leadership, as well as the imposition of unwanted candidates led to violent eruptions in several cases (see CODEO 2005, 5; CODEO 2008, 1).

While the interference from above is one factor that distorts the nomination process, financial capability is another. Local candidates receive little or no support from the central party and so they usually have to finance their campaigns from their own funds. This excludes candidates with little financial capacity from even contesting their own party's primaries. There are often three or four contestants for the parliamentary slot who try to set up competing clientelistic networks within the local party to secure their nomination (see CODEO 2005, 25). This makes the whole process extremely expensive. Some of those who have to struggle through their party primaries are actually bankrupt before the election take place.

While the expenditures in the primaries and parliamentary elections are enormous, they are exorbitant in the competition for the presidential slot. As a consequence, the top level positions in the political system are reserved to a small circle of extremely wealthy individuals, while the poor are excluded from rising in the party hierarchy. This means that, while Ghanaian parties nominally fulfil the function of candidate nomination, they do not always nominate the most able candidates, but rather those who are rich enough to engage in the political game.

\section{Discussion and concluding remarks}

Do political parties in Ghana fulfil their functions? According to the framework developed by Gunther and Diamond the answer is: yes, partly. They mobilise voters, 
they name candidates and form governments. The fact that they at least provide a rough ideological guidance by being integrated into wider party traditions makes them identifiable and gives some orientation to the voters. Thus, their overall performance is not too bad. It may even be better than that in many other African countries. On the other hand, the Ghanaian parties do not represent or aggregate the interests of well-defined social groups and have serious deficits in ensuring meaningful participation.

It is of course worth noting that parties in Ghana have successfully adapted to the context in which they exist. African parties have little other chance than employing low-tech campaign strategies, such as funeral politics or house-to-house campaigns. Given the absence of strong organised group interest to which parties can appeal, intermediaries have become an important link between parties and voters. Although this could be described as a successful adaptation, the socioeconomic conditions under which African parties operate have some wider implication for political participation and democratic development. The complaint over the difficulty of financing political activities resounded in nearly all field interviews. The eminent role that money plays in politics has two consequences. First, it distorts political competition by disadvantaging small parties with few resources. Secondly, it keeps the rural and urban poor outside of the decision-making process. The exclusion of the poor from an active engagement starts at the grass-roots level, and the monetary entry barrier into the political system rises with every stage in the party hierarchy. What emerges are parties with little internal democracy and little vertical accountability. A local African politician once stated that political parties 'belong' to those who finance them. ${ }^{25}$

Meaningful participation in politics is restricted to the elite. Citizens are mere consumers of politics; they have little influence on decision-making and little chance to exercise their passive voting rights. Democratisation has empowered them to do little more than choosing their leaders from a small circle of big men. On the top level of politics, this leads to a situation where individuals competing for high office are mostly 'of a relatively narrow circle that has been at the political apex for decades' (Chabal 2005, 32). The Busia-Danquah tradition may serve as an example for such leadership continuity. It has:

...traditionally been associated with a highly patrician style of leadership. It has been dominated by certain political families - one might even say dynasties - from the Ashanti and Eastern Regions with a foot in business or the professions, especially law. (Nugent 2007, 260)

The NDC is more pro-poor and social-democratic in appearance, but it provides equally small channels of empowerment. Frustration and disillusionment is almost inevitable because once in government, the main concern of incumbent elites often becomes the preservation of the status quo.

Even if the NDC would take social-democracy more seriously, the scope of action for such an endeavour would be restricted because, as Mkandawire argues, structural adjustment and neoliberal discourses foreclose 'debates on a wide range of issues of political economy' (1999, 124). This makes the new democracies 'choiceless' and of 'low-intensity' (Saul 1997). Obi $(2008,10)$ summarises these problems:

Although the people vote for political parties, the experience in Africa is that they do not have a say in the economic policies of elected governments. We are then increasingly confronted by the situation in which the economic logic overpowers the people's will, 
making nonsense of choices between different candidates that all end up implementing the same economic reforms that punish and disempower the poor people who are in the majority. Multiparty democracy in Africa has been for the affluent and the powerful, more a game of musical chairs in which various individual members of the political elite take their turns at the seat of power, but do not change the music.

Although active and passive voting rights are formally guaranteed, the participation of the poor is reduced to voting in elections. Given the fact that the state is the primary front of accumulation, the poor are thus not only excluded from decision-making but also from an upwards social mobility. Ironically, the freezing of social stratification takes place under the guise of democratisation and greater political freedom. Seen in this way, political parties are instruments of elite competition that reinforce social closure. Under these circumstances, the function that political parties really perform is that of organising and legitimising the rotation of elites in state positions. They organise it by restricting the access to positions in parties and government to a small group of people with a high social status, and they legitimise it by creating the bonds between these elites and the citizens by claiming a shared interest.

Of course we could argue that this is no immediate problem for democracy. The Freedom House measures for Ghana are still excellent. However, whether we do or do not see a problem depends on the definition of democracy. Proponents of procedural understandings often vindicate that the exclusion of social progress makes their approach universal and more realistic (see also Saul 1997, 342). While it can be debated whether social rights should be a part of the definition, or how much participation democracy needs, the findings of this study show that endemic poverty and weakly developed infrastructures practically hinder grassroots participation even in procedurally wellfunctioning democracies like Ghana. This highlights a general problem: by reducing democracy to its formal aspects, the paradigm ignores the unequal distribution of social capital and implicitly assumes that formally granted equal rights correspond with equal chances to exercise these rights. This may have always been an illusion even in the West, as the development of the competing model of social democracy shows. Today, as Katz and Mair $(1995,22)$ argue, electoral democracy may be a means by which the rulers control the ruled, rather than the other way around. Yet, Western democracies still offer more avenues for participation than African systems do. Thanks to higher living standards and intact infrastructures, even small parties can maintain a certain degree of effective organisation. An example for this is the rise of the 'Pirate Parties' in Europe which use the internet as a platform for political mobilisation. ${ }^{26}$ Such things are impossible in Africa. Thus, the unspoken preconditions for liberal democracy reflect the historical origin of the concept. Representative party democracy with general and free elections is a product of certain historical conditions. Its evolution must be placed in the context of urbanisation, proletarisation, and technical innovations that enhanced mass communication. These structural changes opened certain channels of participation even for subaltern groups and encouraged the imagination of alternative conceptions of democracy. The social-democratic mass parties are the prime example here.

This does not mean that democracy is impossible in Africa. The high approval of democratic forms of government among the African peoples, documented for example in the Afrobarometer data, but also confirmed in various personal communication during the field work for this project, is the most encouraging point. There is a real desire for better leadership and for an improvement of living conditions. Formal institutions are an 
important and necessary benchmark, but they are not sufficient. A deepening of democracy will have to take up the issue of poverty, not only because democratic discourses that are separated from economic development are socially meaningless (Lumumba-Kasongo 1998, 58), but also because improved living standards would enhance the capacity of the citizens to participate in the political process.

\section{Acknowledgements}

I wish to thank Dr. Joseph Asunka and the Centre for Democratic Development (CDD) in Ghana for their generous assistance. I also thank the German Research Foundation (DFG) for providing the funding for this project.

\section{Notes}

1. Dahl developed his theory in his books A Preface to Democratic Theory (1956); Polyarchy (1971) and Democracy and its Critics (1989).

2. According to Huntington (1991), a democracy is consolidated if two peaceful turnovers have occurred after the founding elections.

3. A similar statement was made by Kwame Boafo-Arthur, Head of the Department of Political Science at the University of Legon, Accra. He said that in Ghana 'football and party politics are our favourite sport' (Interview, Accra, 22 March 2007).

4. The question asked in the Afrobarometer survey: 'Do you feel close to one of the political parties in your country?' provides a good starting point for analysis. In 2005 , only a minority of $33.7 \%$ of the respondents were not feeling close to one of the parties. $43.2 \%$ were close to the NPP, $20.5 \%$ to the NDC, $1.5 \%$ to the CPP, $0.9 \%$ to the PNC, and $0.3 \%$ to the NRP (National Reform Party, an NDC-splinter party).

5. In the Ashanti region, this was very clearly expressed. Isaac Twum-Amankwa, constituency secretary of the NPP in Mampong, stated that 'Ashantis are capitalists. They are comfortable with the policies of the government' (10 March 2007, Mampong). In Akan thought, societal and individual achievement was believed to be built upon 'the assiduously pursued process of accumulation' (McCaskie 1995, 37). The early pioneers who cleared the land for settlement and agriculture in the Akan forest were known as abirempon, meaning 'big men'. They were later incorporated into the Asante Empire and their status was formalised (McCaskie 1995). The ceremony of becoming an obirempon entailed a dance in which an elephant is hunted in order to secure its tail; this ceremony was followed by a distribution of largess and a public display of the wealth of the aspirant (43). Hence, the 'big man' was seen as a protector and provider, as is expressed in the proverb: 'It is one man who kills the elephant, but many people who eat its flesh' (44). By choosing the elephant as its party symbol, the NPP makes some obvious references to the Asante system of beliefs and the positive role that is attributed to individual wealth as benefiting the whole community.

6. NDC Manifesto 'A better Ghana', available at www.ndcghanaonline.com/index.php/manifesto

7. Interview with Samuel Owusu-Ampofo, National Organiser NDC, Accra, 10 May 2006.

8. Interview with Akamugri Atanga Donatus, Regional Secretary NDC Upper East, Bolgatanga, 18 March 2006, and with Romeo Hademe, Deputy Secretary NDC South Tongu, Sogakope, 26 March 2007.

9. Interview with Akamugri Atanga Donatus, op. cit.

10. Interview with Fortune T. Abusuasem, Parliamentary Candidate PNC for Hohoe North, 19 March 2006.

11. Results for the Nkrumahists are not shown because of the small N.

12. Interview with Samuel Ofosu Ampofo, 2007, op. cit.

13. Interview with Fortune T.Abusuasem, op. cit.

14. Interview with Peter Sarkodie, then-MP for Mampong, Mampong, 8 May 2006.

15. A 'zongo' is a town quarter in southern Ghana inhabited by Muslim migrants from the north of the country.

16. Interview with M.A.Moomin, National Organiser PNC, Accra, 5 May 2006. 
17. This was confirmed by local NPP politicians in the Volta Region: Interviews with Kornu Nana, Constituency Secretary of the NPP for South Tongu, Sogakope, 26 March 2007; and George Egbenunva, Constituency Organiser of the NPP for Hohoe North, Hohoe, 19 May 2006.

18. See for example: Ashanti NPP is Angry. Ghanaweb General News, 4 September 2007. Online: www.ghanaweb.com/GhanaHomePage///NewsArchive/artikel.php?ID=130110 (Accessed 17 November 2008). See also: Canoe Fishermen Call For Ban On Pair Trawling, Modern Ghana News, 12 May 2008, http://www.modernghana.com/news/165004/1/canoe-fishermen-call-forban-on-pair-trawling.html (Accessed 13 December 2008).

19. Personal communication, Bolgatanga, 18 March 2007.

20. Personal communication, Mampong, 13 March 2007.

21. Funerals are important social events in Ghana. Using funerals for political party issues is not new and has been described as 'funeral politics' by Jonah $(1998,87)$.

22. Only the office of the NPP in Hohoe had daily opening hours and a fulltime secretary.

23. Interview with Emmanuel Azinoko, Chairman of the PNC in the Volta Region in an interview on 17 May 2006, Hohoe North.

24. Interview with Fortune T.Abusuasem, op. cit.

25. Interview with Cheikh Kébé, Secretaire de la Délégation Communale de Tamba, AFP, Tambacounda, 30 November 2007.

26. The 'Pirates' aim at reforming copyright laws and protecting the right to privacy. For more on their campaign in Germany see for example www.sueddeutsche.de/politik/240/487644/text/ (accessed: 19 October 2009).

\section{Note on contributor}

Anja Osei received her Ph.D. degree from the African Studies Institute at the University of Leipzig. This project dealt with strategies of party voter-linkage in Ghana and Senegal and included extensive fieldwork in the two countries. Anja currently holds a Postdoctoral position at the University of Konstanz in the Department of Politics and Management. Her research interests lie in the field of African politics and political sociology with a particular focus on democratisation, statesociety relations and neopatrimonialism. She is currently working on a project entitled Elite Networks in Africa which deals with political elites and their formal and informal networks. Anja can be contacted at: Anja.Osei@uni-konstanz.de

\section{References}

Aké, C. 2000. The Feasibility of Democracy in Africa. Dakar: Council for the Development of Social Science Research in Africa.

Basedau, M., G. Erdmann, and A. Mehler. 2007. "Conclusion. The Research Agenda Ahead." In Votes, Money and Violence, edited by M. Basedau, G. Erdmann, and A. Mehler, 176-293. Uppsala: Nordiska Afrikainstitutet.

Berman, S. 2007. "Lessons from Europe." Journal of Democracy 18 (1): 28-41. doi:10.1353/ jod.2007.0000.

Bleck, J., and van de Walle, N. 2011. "Parties and Issues in Francophone West Africa: Towards a Theory of Non-Mobilization." Democratization 18(5), 1125-1145. doi:10.1080/13510347.2011. 603473.

Boafo-Arthur, K. 2003. "Political Parties and Democratic Sustainability in Ghana, 1992-2000." In African Political Parties. Evolution, Institutionalisation and Governance, edited by M. M. A. Salih, 207-238. London: Pluto Press.

Bob-Milliar, G. M. 2012. "Party Factions and Power Blocs in Ghana: A Case Study of Power Politics in the National Democratic Congress Party." The Journal of Modern African Studies 50 (4): 573-601. doi:10.1017/S0022278X12000481.

Bratton, M. and van de Walle, N. 1997. Democratic Experiments in Africa. Cambridge: Cambridge University Press.

Burnell, P. 2007. "Political Parties in Africa: Different, Functional and Dynamic? Reflections on Gero Erdmanns' Party Research: The Western European Bias and the 'African Labyrinth'." 
In Votes, Money and Violence, edited by M. Basedau, G. Erdmann, and A. Mehler, pp. 65-81. Uppsala: Nordiska Afrikainstitutet.

Carothers, T. 2006. Confronting the Weakest Link. Aiding Political Parties in New Democracies. Washington, DC: Carnegie Endowment for International Peace.

Chabal, P. 2005. "Power in Africa Reconsidered." In The African Exception, edited by U. Engel and G. R. Olsen, 17-34. Aldershot: Ashgate.

CODEO (Coalition of Domestic Election Observers). 2005. Ghana's Election 2004. What the Observers Say. Accra: CDD (Center for Democratic Development) Ghana.

CODEO (Coalition of Domestic Election Observers). 2008. Report on the Pre-Election Scenario for June 2008. Accra: CDD (Center for Democratic Development) Ghana.

Daddieh, C. K., and G. M. Bob-Milliar. 2012. "In Search of 'Honorable' Membership: Parliamentary Primaries and Candidate Selection in Ghana." Journal of Asian and African Studies 47(2): 204-220. doi:10.1177/0021909611421905.

Dahl, R. A. 1956. A Preface to Democratic Theory. Chicago: University of Chicago Press.

Dahl, R. A. 1971. Polyarchy: Participation and Opposition. New Haven: Yale University Press.

Dahl, R. A. 1989. Democracy and its Critics. New Haven: Yale University Press.

Debrah, E. 2004. "The Politics of Elections. Opposition and incumbency in Ghana's 2000 Elections." Africa Insight 34 (2/3): 3-15. http://www.ajol.info/index.php/ai/article/view/22397.

Diamond, L. 1994. "Rethinking Civil Society. Towards Democratic Consolidation." Journal of Democracy 5 (3): 4-17. doi:10.1353/jod.1994.0041.

Diamond, L. J. 2002. "Elections without Democracy. Thinking About Hybrid Regimes." Journal of Democracy 13 (2): 21-35. doi:10.1353/jod.2002.0025.

Downs, A. 1957. An Economic Theory of Democracy. New York: Harper.

Elischer, S. 2008. "Measuring and Comparing Political Ideology in Africa." Paper presented at the United States African Studies Association, 13-16 November, Chicago.

Emminghaus, C. 2002. "Politische Parteien und ihre Funktion in afrikanischen Demokratien. Analysekonzept und empirische Befunde zu Botswana und Namibia [Political Parties and their Functions in African Democracies. Approach and Empirical Results in Botswana and Namibia]." Afrika Spectrum 37 (3): 287-309. http://www.jstor.org/stable/40174947.

Erdmann, G. 2002. "Zur Typologie politischer Parteien in Afrika [The Problem of a Typology of Political Parties in Africa]." Afrika Spectrum, 37, 259-285. http://www.jstor.org/stable/40174946.

Erdmann, G. 2004. "Party Research: The WESTERN EUROPEAN BIAS and the "African Labyrinth'." Democratization 11 (3): 63-87. doi:10.1080/1351034042000238176.

Erdmann, G. 2010. Lessons to Be Learned: Political Party Research and Political Party Assistance. GIGA Working Paper 149. Hamburg: GIGA (German Insititute of Global and Area Studies).

Gunther, R., and J. R. Montero. 2002. "Introduction: Reviewing and Reassessing Parties." In Political Parties: Old Concepts And New Challenges, edited by R. Gunther, J. R. Montero, and J. Linz, 3-39. London: John Hopkins University Press.

Gunther, R., and L. Diamond. 2001. "Types and Functions of Parties." In Political Parties and Democracy, edited by L. Diamond and R. Gunther, 3-39. London: John Hopkins University Press.

Gyimah-Boadi, E. 1999. "The Challenges of Consolidating Democracy." In State, Conflict and Democracy in Africa, edited by R. Joseph, 409-427. Boulder: Lynne Rienner.

Huntington, S. 1991. The Third Wave: Democratization in the Late Twentieth Century. Norman: Oklahoma University Press.

Jeffries, R. 1980. "The Ghanaian Elections of 1979." African Affairs 79 (316): 397-414. http:// www.jstor.org/stable/722047.

Jeffries, R., and C. Thomas. 1993. "The Ghanaian Elections of 1992." African Affairs 92 (368): 331-366. http://www.jstor.org/stable/723287.

Jonah, K. 1998. "Political Parties and the Transition to Multi-Party Politics in Ghana." In GhanaTransition to Democracy, edited by K. A. Ninsin, 83-107. Dakar: CODESRIA.

Katz, R., and P. Mair 1995. "Changing Models of Party Organization and Party Democracy: The Emergence of the Cartel Party." Party Politics 1 (1): 5-28. doi:10.1177/1354068895001001001.

Kirchheimer, O. 1966. "The Transformation of the Western European Party System." In Political Parties and Political Development, edited by J. LaPalombara and M. Weiner, 177-200. Princeton: Princeton University Press.

Lumumba-Kasongo, T. 1998. The Rise of Multipartyism and Democracy in the Context of Global Change. London: Praeger. 
Lynch, G., and G. Crawford. 2011. "Democratization in Africa 1990-2010: An Assessment." Democratization 18 (2): 275-310. doi:10.1080/13510347.2011.554175.

Manning, C. 2005. “Assessing African Party Systems after the Third Wave." Party Politics 11 (6): 707-727. doi:10.1177/1354068805057606.

Mansfield, E. D., and J. L. Snyder. 2005. Electing to Fight. Why Emerging Democracies Go to War. Cambridge: MIT Press.

McCaskie, T. C. 1995. State and Society in Pre-Colonial Asante. Cambridge: Cambridge University Press.

Mkandawire, T. 1999. "Crisis Management and the Making of 'Choiceless Democracies'." In State, Conflict, and Democracy in Africa, edited by R. Joseph, 119-136. Boulder: Lynne Rienner.

Nugent, P. 2007. "Banknotes and Symbolic Capital." In Votes, Money and Violence, edited by M. Basedau, G. Erdmann, and A. Mehler, 252-275. Uppsala: Nordiska Afrikainstitutet.

Nwosu, B. U. 2012. "Tracks of the Third Wave: Democracy Theory, Democratisation and the Dilemma of Political Succession in Africa." Review of African Political Economy 39 (131): 11-25. doi:10.1080/03056244.2012.658717.

Obi, C. I. 2008. "No Choice but Democracy. Prising the People out of Politics in Africa?" Claude Ake Memorial Papers No. 2. Uppsala Department of Peace and Conflict Research, Uppsala University \& Nordiska Afrikainstitutet.

Olukoshi, A. O. 1998. Economic Crisis, Multipartyism, and Opposition Politics in Contemporary Africa. In The Politics of Opposition in Contemporary Africa, edited by A. O. Olukoshi, 8-38. Uppsala: Nordiska Afrikainstitutet.

Poguntke, T. 2003. Internationale vergleichende Parteienforschung [Comparative Political Parties]. In Vergleichende Politikwissenschaft. Ein einführendes Studienhandbuch [Comparative Political Science], edited by D. Berg-Schlosser and F. Müller-Rommel, 189-206. Wiesbaden: VS Verlag für Sozialwissenschaften.

Posner, D. N. 2005. Institutions and Ethnic Politics in Africa. Cambridge: Cambridge University Press.

Rakner, L., and N. van de Walle 2009. "Opposition Weakness in Africa." Journal of Democracy 20 (3): 108-121. doi:10.1353/jod.0.0096.

Randall, V., and L. Svåsand. 2002. "Party Institutionalization in New Democracies." Party Politics 8 (1): 5-29. doi:10.1177/1354068802008001001.

Sartori, G. 1970. "Concept Misformation in Comparative Politics." The American Political Science Review 64 (4): 1033-1053. doi:10.2307/1958356.

Saul, J. S. 1997. "For Fear of Being Condemned as Old Fashioned: Liberal Democracy versus Public Democracy in Sub-Saharan Africa." Review of African Political Economy 73: 339-353. doi:10.1080/03056249708704267.

Sindjoun, L. 2010. "Introduction to Political Parties and Democracy: Part 1: Africa: Which makes which?" In Political Parties and Democracy: Africa and Oceania, edited by K. Lawson, L. Sindjoun, and M. Simms, 3-7. Westport: Greenwood Publications Group.

Tetzlaff, R. 2002. "Zur Renaissance der politischen Parteien und Parteienforschung in Afrika [The Renaissance of Political Parties and Party Research in Africa, Introduction]." Africa Spectrum 37 (3): 239-257. http://www.jstor.org/stable/40174945.

Therborn, G. 1977. "The Rule of Capital and the Rise of Democracy." New Left Review 103: 3-41.

Uddhammar, E., E. D. Green, and J. Söderström. 2011. "Political Opposition and Democracy in Sub-Saharan Africa." Democratization 18 (5): 1057-1066. doi:10.1080/13510347.2011.603466. van Cranenburgh, O. 1999. International Policies to Promote African Democratization. In Democracy without Borders: Transnationalization and Conditionality in new democracies, edited by J. Grugel, 92-105. New York and London: Routledge.

van de Walle, N. 2003. "Presidentialism and Clientelism in Africa's Emerging Party Systems." Journal of Modern African Studies 41 (2): 297-321. doi:10.1017/S0022278X03004269.

von Alemann, U. 2002. Parteien in der Mediendemokratie [Parties in the Media Democracy]. Wiesbaden: Westdeutscher Verlag.

von Beyme, K. 1982. Parteien in westlichen Demokratien [Parties in Western Democracies]. München: Piper.

von Beyme, K. 2000. Parteien im Wandel [Party Change]. Wiesbaden: Westdeutscher Verlag.

Wiesendahl, E. 1980. Parteien und Demokratie. Eine soziologische Analyse paradigmatischer Ansätze in der Parteienforschung [Parties and Democracy. A Sociological Analysis of Paradigmatic Approaches in Party Research]. Opladen: Leske + Budrich. 
Widner, J. A. 1997. "Political Parties and Civil Societies in Sub-Saharan Africa." In Democracy in Africa. The Hard Road Ahead, edited by M. Ottaway, 65-82. Boulder: Lynne Rienner.

Wiseman, J. A. 1998. The New Struggle for Democracy in Africa. Aldershot: Ashgate.

Whitfield, L. 2009. "“Change for a Better Ghana': Party Competition, Institutionalization and Alternation in Ghana's 2008 Elections." African Affairs 108 (433): 621-641. doi:10.1093/afraf/ adp056. 